\title{
Group A $\beta$-hemolytic Streptococcus Detection Using Anti-Outer Membrane Protein (OMP) Immunoglobulin G (IgG)
}

\author{
Ema Dianita Mayasari ${ }^{1 *}$, Hamid Hunaif Dhofi Alluza $^{1}$, Sumarno $^{2}$, Sri Winarsih ${ }^{2}$
}

\footnotetext{
${ }^{1}$ Laboratory of Biomedical Science, Faculty of Medicine, Brawijaya University, Malang, Indonesia
}

${ }^{2}$ Laboratory of Microbiology, Faculty of Medicine, Brawijaya University, Malang, Indonesia

\begin{abstract}
Streptococcal pharyngitis sequel such as Rheumatic Fever (RF) or Rheumatic Heart Disease (RHD) is an autoimmune response mediated by $\mathrm{T}$ cells and IgG. Since it is an autoimmune process, the result of bacterial culture as the gold standard of diagnosis often shows negative results. IgG against the $33 \mathrm{kDa} O M P$ is considered as an important mediator in the process of these autoimmune dis eases, so its presence in blood serum can be used as a diagnostic tool. The purpose of this study is to prove that $33 \mathrm{kDa}$ OMP is one of the immunogenic parts of the Streptococcus Group A $\beta$-hemolytic, so it is expected that IgG anti-33 kDa OMP can recognize and respond the bacteria and to support the probability of the Streptococcus Group A $\beta$-hemolytic infection. This study was a laboratory experimental study with a control group design. Animal used was RattusNovergicus immunized with whole cell bacteria or $33 \mathrm{kDa}$ OMP mixed with Complete Freund's Adjuvant or Incomplete Freund's Adjuvant. Polyclonal IgG was obtained by drawing blood serum from the animals after immunization with Streptococcus Group A $\beta$-hemolytic for 4 weeks $(A ; n=5)$ and 8 weeks $(B ; n=5)$ or immunization with OMP $33 \mathrm{kDa}$ for 4 weeks $(C ; n=5)$ and 8 weeks $(D ; n=5)$ and also negative control group $(E ; n=5)$. Immunological tests were done using Dot Blot assay, ELISA, and immunocytochemical examination. The data obtained was then evalu ated with statistical tests Kruskal-Wallis, Mann-Whitney and Repeated ANOVA $(\mathrm{p}<0.05)$. The result showed that there was a difference in humoral immune response (IgG) between the groups albeit the difference was not significant $(p>0.05)$. Dot Blot and im munocytochemical tests indicated that IgG anti-33 kDa OMP were able to recognize and respond the Streptococcus Group A $\beta$ hemolytic antigen. This study concluded that $33 \mathrm{kDa}$ OMP was the immunogenic part of the bacteria and that $\operatorname{IgG}$ anti- $33 \mathrm{kDa}$ OMP could recognize and respond the Streptococcus Group A $\beta$-hemolytic bacteria.
\end{abstract}

Keywords: Streptococcus group A $\beta$-hemolytic, $33 \mathrm{kDa} O M P$, IgG anti-33 kDa OMP

\section{INTRODUCTION}

Streptococcus group A $\beta$-hemolytic infection can trigger an autoimmune response in approximately $0.3-$ $3 \%$ of the population, leading to Rheumatic Fever (RF) and Rheumatic Heart Disease (RHD) that can cause functional impairment of the heart and death [1]. The incidence rate of RHD varies in several countries, 21.5 per 1000 population in Cambodia, 30.4 per 1000 population in Nicaragua and 62 per 1000 population in Kenya. Approximately 62-78 million people in the world suffer from RHD, with 1.4 million deaths from RHD or its complications [2].

The gold standard for the diagnosis of RF and RHD is bacterial culture. Meanwhile, RF and RHD are

\footnotetext{
*Corresponding author:

Ema Dianita Mayasari

Laboratory of Biomedical Science, Faculty of Medicine,

Brawijaya University, Malang, Indonesia

Jalan Veteran, Malang, Indonesia 65145

E-mail: emadianita@gmail.com
}

established chronic autoimmune diseases in which IgG plays an important role to mediate the host tissue damage. The specificity of $\operatorname{IgG}$ is actually directed to the streptococcal antigen, such as M Protein. In the previous study, M Protein allegedly plays a role as a virulence factor of Streptococcus group A $\beta$-hemolytic [3]. Unfortunately, this M Protein may have structural similarities with tropomyosin, vimentin, and laminin from the human heart valve $[4,5]$, in which IgG anti-M Protein may cause cross-reaction and attack the human heart valve, leading to valve destruction.

$\mathrm{M}$ Protein forms fimbriae and is a part of streptococcal Outer Membrane Protein (OMP) [3, 5]. Previous study by Fischetti showed that M Protein had 33

How to cite:

Mayasari ED, Alluza HHD, Sumarno, Winarsih S (2017)

Group A $\beta$-hemolytic Streptococcus Detection Using

Anti-Outer Membrane Protein (OMP) Immunoglobulin G

(IgG). J. Trop. Life. Science 7 (1): 8 - 15. 
$\mathrm{kDa}$ of molecular weight [6]. IgG anti- $33 \mathrm{kDa} O \mathrm{OMP}$ may be considered as the one that mediates the autoimmune response in RF and RHD. This provides an opportunity for researchers to develop IgG anti-33 kDa OMP as a detection material for Streptococcus group A $\beta$-hemolytic.

The objective of this study is proving that $33 \mathrm{kDa}$ OMP is the immunogenic antigen of the bacteria which promotes immune response of the host. Therefore, the presence of $\mathrm{IgG}$ anti-33 $\mathrm{kDa}$ OMP in the serum indicates that the host has been infected by the bacteria. Supported by clinical manifestations, this method can be developed as a standard to diagnose RF and RHD.

\section{MATERIALS AND METHODS}

Outer Membrane Protein (OMP) isolation of Streptococcus group $\boldsymbol{A} \boldsymbol{\beta}$-hemolytic

OMP isolation was done by mixing NOG $0.5 \%$ (nOctyl- $\beta$-D-Glucopyranoside) with the cultured bacterial pelletin liquid in Todd Hewitt Broth medium. Supernatant obtained after centrifugation $12500 \mathrm{G}$ was taken and then dialyzed, so it could be used for further process [7].

\section{Sodium Dodecyl Sulfate Polyacrylamide Gel Elec- trophoresis (SDS-PAGE)}

OMP proteins were separated based on their molecular weight by using electrophoresis method used by Laemli in his study in 1970 [8]. Protein sample was heated at $100^{\circ} \mathrm{C}$ temperature for 5 minutes in liquid buffer containing 5 mMTris $\mathrm{pH}$ 6.8, 5\% 2-mercapto ethanol; $2.5 \% \mathrm{w} / \mathrm{v}$ sodium dodecyl sulfate, $10 \% \mathrm{v} / \mathrm{v}$ glycerol with bromophenol blue tracer color. Gel slab $12.5 \%$ with tracking gel $4 \%$ was selected. $120 \mathrm{mV}$ voltage electricity was used to run the process. Coomassie brilliant blue was used. Protein markers were purchased from ferments [8].

\section{Isolation of Streptococcal $33 \mathrm{kDa}$ OMP (by electroelu- tion)}

Electroelution was done first by cutting the $33 \mathrm{kDa}$ protein ribbon (SDS-PAGE result). The desired band was then inserted into dialysis membrane tube using electrophoresis-running-buffer. Electroelution was done by using a horizontal electrophoresis at a voltage of $125 \mathrm{mV}$ for 25 minutes. Dialysis was done after the electroelution result was obtained, with PBS $\mathrm{pH} 7.4$ buffer as much as $2 \mathrm{~L}$ during $2 \times 24$ hours. The dialysis fluid was replaced three times. The end result of this process was then ready to be used for further examina- tion [9].

\section{Immunization of experimental animals Rattusnorvegi- cus}

Rat (Rattus norvegicus) were divided into 5 groups $(\mathrm{A}, \mathrm{B}, \mathrm{C}, \mathrm{D}, \mathrm{E})$ and immunized by injecting the antigens (Streptococcus group A $\beta$-hemolytic whole bacteria or $33 \mathrm{kDa}$ OMP) intraperitoneally. Group A was immunized with Streptococcus group A $\beta$-hemolytic whole bacteria and the booster every week, as much as 4 times, thereby achieving an incubation period of 4 weeks $(n=5)$. Group B was immunized with Streptococcus group A $\beta$-hemolytic whole bacteria and the booster every week, as much as 8 times, thereby achieving an incubation period of 8 weeks $(n=5)$. The Streptococcus group A $\beta$-hemolytic used had a density of 109 in 0.5 cc PBS in each injection. Group C was immunized with $33 \mathrm{kDa}$ OMP and the booster every week, as much as 4 times, thereby achieving an incubation period of 4 weeks $(n=5)$. Group $\mathrm{D}$ was immunized with $33 \mathrm{kDa}$ OMP and the booster every week, as much as 8 times, thereby achieving an incubation period of 8 weeks $(n=5)$. Group E was a negative control group, composed of healthy rats without any immunization $(\mathrm{n}=5)$. The dosage of each $33 \mathrm{kDa}$ OMP immunization was $100 \mu \mathrm{g}$. At first immunization, Complete Freund's Adjuvant was used as a combination. One week after incubation period, blood serum was taken and then $\operatorname{IgG}$ was isolated $[10,11]$.

\section{Isolation of polyclonal antibodies from blood serum}

Blood was drawn from the heart. Blood was taken from 25 rats, then put into a sterile tube and stored in an incubator at $37^{\circ} \mathrm{C}$ in an upright position for 30 minutes. It was then stored in the refrigerator with $4^{\circ} \mathrm{C}$ temperature for 10 minutes and centrifuged at 10,000 rpm for 5 minutes. Clear liquid at the top was separated from the blood clot underneath, and placed in a sterile tube and stored at $20^{\circ} \mathrm{C}$ temperature [12].

\section{Dot blot assay}

An immunological test used for detecting IgG-antigen bond was done using Dot Blot assay. The desired antigen was put on nitrocellulose membrane through the Dot Blot wells according to the number of samples. Blocking was done with TBS-skim 5\% and incubated overnight at $4^{\circ} \mathrm{C}$ temperatures. Primary antibodies from the host's blood serum were inserted into each hole as much as $50 \mu \mathrm{L}$ and incubated for 1 hour at room temperature. A secondary anti-rat antibody with the same volume was then inserted, followed by SA- 
HRP and Western Blue TMB substrate so that the Dot Blot results could be read.

\section{Enzyme Linked Immunosorbent Assay (ELISA)}

Investigation of the level of IgG was performed using ELISA method [8], using anti-Rat IgG obtained from Affymetrix's Bioscience with catalog number 134813. Parameters measured were the level of IgG represented by Optical Density (OD). $5 \mu \mathrm{L}$ antigens were added in a coating buffer with a ratio of 1: 9 in wells plate. The eppendorf was wrapped in aluminum foil and incubated overnight at a $4^{\circ} \mathrm{C}$ temperature. It was then washed with PBS-Tween. $50 \mathrm{~mL}$ of blocking buffer $(1 \%$ BSA in PBS) was then added. It was incubated for 2 hours at $37^{\circ} \mathrm{C}$ temperature then washed with PBS-Tween. $100 \mathrm{~mL}$ of primary antibody in PBS-BSA solution of $1 \%$ with a ratio of $1: 25$ was added. It was then incubated for 2 hours at a $37^{\circ} \mathrm{C}$ temperature. After that it was washed with PBS-Tween. $100 \mu \mathrm{l}$ of secondary antibody (anti Rat-IgG) in the Tris Buffer Saline with the ratio of $1: 1000$ was then added. It was then incubated for 1.5 hours at a $37^{\circ} \mathrm{C}$ temperature. 50 $\mu \mathrm{L}$ TMB substrate was added in a dark room. It was then incubated for 30 minutes at room temperature in a dark room. As much as $50 \mu \mathrm{L} \mathrm{H}_{2} \mathrm{SO}_{4}$ stop solution was added. It was then incubated for 10 minutes at room temperature. Its absorbance was read with ELISA reader at a wavelength of $450 \mathrm{~nm}$.

\section{Immunocytochemical examination with fluorescence}

The antigen used for this test was Streptococcus group A $\beta$-hemolytic whole bacteria. $1 \mathrm{ml}$ of bacterial cell suspension with the density of 109 was centrifuged at $200 \mathrm{G}$ speed for 5 minutes. The pellet was then taken and then added with $50-100 \mu \mathrm{L}$ primary antibody with the concentration of $10-20 \mu \mathrm{g} / \mathrm{mL}$. The secondary antibody used was FITC secondary anti-rat IgG. After incubation on ice for 30 minutes, the cells were washed with PBS $3 \times$, then suspended again in 2 drops of PBS. The suspension was then smeared on cover glass and observed with fluorescence convocal microscope [13].

\section{Data analysis}

A statistical test was done using SPSS version 20.0. Normality test was done using Shapiro-Wilk. Data distribution was not normal ( $\mathrm{p}<0.05$ ), comparison test between groups was done by using Kruskal-Wallis, Mann-Whitney and Repeated ANOVA. In this study, the value of Confidence Interval is $95 \%$ and $\mathrm{p}<0.05$ [14].

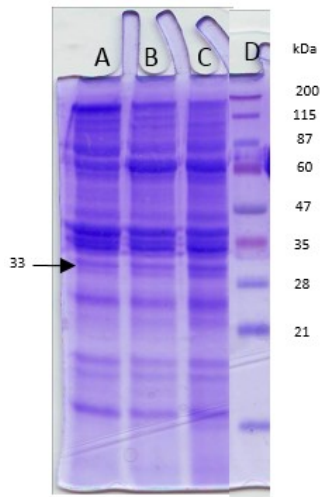

Figure 1. Profile analysis of OMP using NOG $0,5 \%$ as the detergent with SDS-PAGE method in 3 times-triplicate. (A) OMP; isolation using NOG 0.5\% (1), (B) OMP; isolation using NOG 0.5\% (2), (C) OMP; isolation using NOG $0.5 \%$ (3) and (D) marker

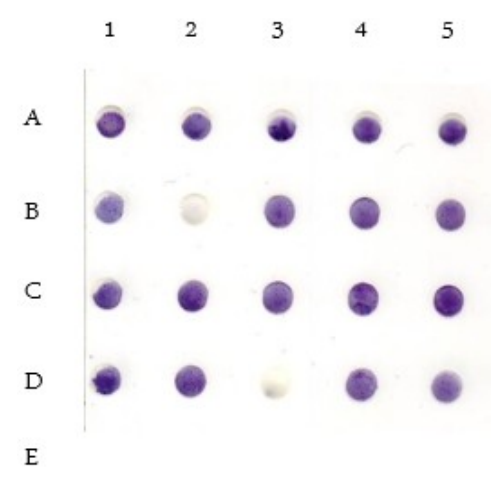

Figure 2. Immune complex density using Dot Blot assay. There are five rat serums: (1) $\operatorname{IgG} \mathrm{n} 1,(2) \operatorname{IgG} \mathrm{n} 2,(3) \operatorname{IgG}$ $\mathrm{n} 3$, (4) $\operatorname{IgG} \mathrm{n} 4$, and (5) IgG n5. There are also five groups: (A) immunized with whole cell bacteria for 4 weeks, (B) immunized with whole cell bacteria for 8 weeks, (C) immunized with OMP 33 kDafor 4 weeks, (D) immunized with OMP $33 \mathrm{kDafor} 8$ weeks, and (E) negative control.

\section{RESULTS AND DISCUSSION}

Profile analysis of OMP of Streptococcus group $A \beta$ hemolytic

The electrophoresis result above showed that there were proteins with $33 \mathrm{kDa}$ of molecular weight in the OMP of Streptococcus group A $\beta$-hemolytic that was isolated using NOG $0.5 \%$. This was the protein target used for immunizations and other immunologic tests done in this study.

\section{Detection of anti-33 $\mathrm{kDa}$ OMP IgG based on immune complex density using Dot Blot assay}

Based on the test results performed on the checkerboard explorative test, it was shown that the concentra- 
tion of antibodies used for dot blot were 1/25600 and antigen $3.125 \mu \mathrm{g} / \mathrm{mL}$. To explore the bond of IgGOMP $33 \mathrm{kDa}$ in each group, Dot Blot test were used using $33 \mathrm{kDa}$ OMP antigen isolated earlier. The result was described in Figure 2 and Figure 3.

Since the distribution of the data obtained from dot blot assay was not normal (Shapiro-Wilk $\alpha<0.05$ ), the comparison test used was Kruskal-Wallis followed with Mann-Whitney test. The data obtained by KruskalWallis test showed the mean rank as illustrated in Figure 3, which was $\mathrm{E}>\mathrm{B}>\mathrm{D}>\mathrm{A}>\mathrm{C}$. The Chi Square value was 15.338 with $p=0.004$, meaning that there was a significant difference between groups of experimental animals. To observe the differences, a comparison test using Mann-Whitney method was conducted (Figure 3).

It was explained earlier that the results above reflected the value of dot blot's brightness level, which was inversely proportional to the density of the formed immune complexes. Thus, from the data above, it could be seen that the highest density of immune complexes was observed in group $\mathrm{C}$, which was the group of animals immunized with $33 \mathrm{kDa} \mathrm{OMP}$ with an incubation period of 4 weeks.

Dot blot is an immunologic test used to detect interactions between antigen and antibody. By conducting this test, we can discover that an antigen has an immunogenic profile and how much the host responds to that antigen. The data obtained from this test is a ratio that shows how many immune complexes are formed. Based on the results of Dot Blot assay in this

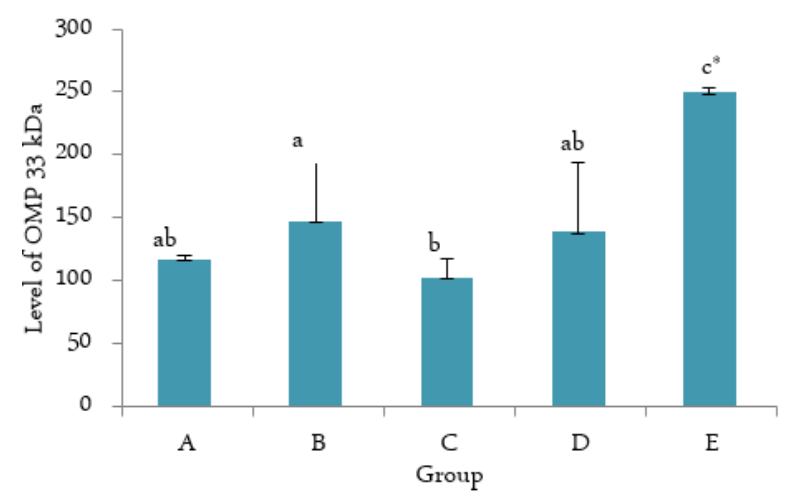

Note: * significantly different

Figure 3. Level of Dot Blot OMP $33 \mathrm{kDa}$ antigen using secondary anti-rat IgG in five different groups: (A) immunized with whole cell bacteria for 4 weeks, (B) immunized with whole cell bacteria for 8 weeks, (C) immunized with OMP $33 \mathrm{kDafor} 4$ weeks, (D) immunized with OMP $33 \mathrm{kDafor} 8$ weeks, and (E) negative control. study, using $33 \mathrm{kDa}$ OMP antigen, it appeared that there was a difference between the mean values of each group of experimental animals. Because the ratio data reflected the level of brightness, so the color density showing immune complexes was inversely proportional to the number shown, meaning that the immune complexes shown in the dot blot result were $\mathrm{C}>\mathrm{A}>\mathrm{D}>\mathrm{B}$ $>\mathrm{E}$. This finding was supported by the result of ELISA test, which was $\mathrm{A}>\mathrm{C}>\mathrm{B}>\mathrm{D}>\mathrm{E}$.

To determine the relationship between the type of immunization with the humoral immune response, we compared group A (whole cell bacteria immunization for 4 weeks) and C (33 kDa OMP immunization for 4 weeks). As shown in Chart 1, the mean value of group A was higher than group $C$, suggesting that the density of immune complexes in group $\mathrm{C}$ was higher than group A. It can be inferred that immunization with 33 $\mathrm{kDa}$ OMP induces humoral immune response more than the whole cell bacteria immunization. With ELISA test, group A had a slightly higher level of IgG than group $C$ but not significant $(p=0.465)$. This is consistent with the theory described in the textbook of Immunobiology by Janeway et al (2001) stating that stimulus by bacterial peptide will direct the immune response towards Th1 which will then activate the cellular immune response, whereas stimulation by the peptide-specific antigen, will lead to a Th2 immune response and ultimately enable cells to produce Ig. However, these differences were not statistically significant $(\alpha>0.05)$. This might be caused by the large Standard Deviation of the data which possibly occured as a result of the small number of the samples [15].

The relationship between incubation period with a humoral immune response is determined by comparing group $\mathrm{A}$ and $\mathrm{B}$, as well as group $\mathrm{C}$ and $\mathrm{D}$. The data obtained from dot blot assay and ELISA indicated that the group immunized within 4 weeks responses better than the group immunized within 8 weeks. Abbas and Lichtman (2011) stated the same theory that the serum IgG half-life is 23 days [16]. As well as Janeway et al who showed that serum IgG level will increase 10-100 fold after secondary antigen exposure. However, mature B cells circulating in the blood has a half life of 12 months post infection and a little longer on $\mathrm{B}$ cell memory [15]. It means that $\mathrm{IgG}$ production will begin to decline after that time. It explains why this study found that the immune complexes recorded on dot blot assay were higher in 4 weeks immunization groups compared to 8 weeks groups. It was probably caused by a normal process of the host's downregulation.

This study still has shortcomings because it could 
not explain the pattern of increased or decreased levels of IgG because the sampling is only performed three times: before immunizations, 4 weeks of immunizations, and 8 weeks of immunizations. Thus, further research is needed in which the serum sampling should be done more often, such as day 0 , week 1, week 2, 3, 4, 5 and so on. So it could better explain the increased or decreased level of IgG by the time.

The medical purpose of determining the IgG levels at 4 and 8 weeks is that this data can be used as a rationale to determine the best time to do laboratory examination in patients suspected with Streptococcus group A $\beta$-hemolytic infection, so we can obtain a true-positive and cost-effective result. However, to achieve that, epidemiological studies are necessary regarding the levels of anti-streptococcus IgG in humans, either diseased or non-diseased, because of the possibility of positive anti-Streptococcus IgG result in healthy person, especially in developing countries, so clinicallysignificant-levels of $\operatorname{IgG}$ must be determined. In addition, this data can also be used as a reference to determine the best time to do the booster for the streptococcal vaccine, either active or passive immunization.

\section{IgG levels measured by ELISA}

Measurement of IgG was done through Optical Density at $450 \mathrm{~nm}$ of wavelength in the ELISA which was directly proportional to the level of IgG. From the results, as shown in Figure 4, it was observed that group $\mathrm{E}$ (negative control) was significantly different from any other immunized group. Comparison between group $\mathrm{C}$ (33 $\mathrm{kDa}$ OMP immunization for 4 weeks) and group A (whole cell of bacteria immuniza-

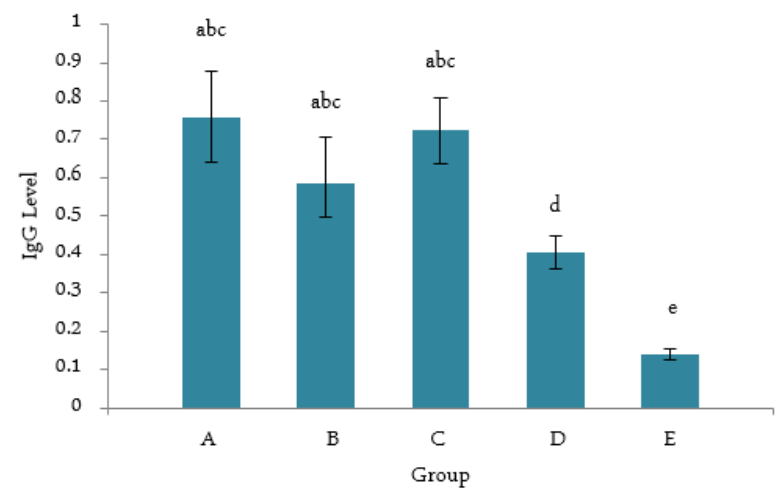

Figure 4. Level of IgG in five different groups was measured by ELISA: (A) immunized with whole cell bacteria for 4 weeks, (B) immunized with whole cell bacteria for 8 weeks, (C) immunized with OMP $33 \mathrm{kDafor} 4$ weeks, (D) immunized with OMP $33 \mathrm{kDafor} 8$ weeks, and (E) negative control. tion for 4 weeks) showed that there was no significant difference, but in 8 weeks immunization groups (B and D), it was shown that there was a significant difference $(p=0.009)$, in which group B reached a higher level of $\mathrm{IgG}$, about $150 \%$ of group D. Whereas the IgG levels in group with 4 weeks $33 \mathrm{kDa}-\mathrm{OMP}$ immunization (group C) was much higher than in group with 8 weeks immunizations groups (group D). The difference was approximately $175 \%$ from group $\mathrm{D}(\mathrm{p}=$ 0.009 ).

\section{Analysis of the Binding of anti-33 $\mathrm{kDa} O M P$ IgG with- Streptococcus group $A \beta$-hemolytic}

From the above Dot Blot test, it was observed that the best IgG-33 $\mathrm{kDa}$ OMP binding was in group $\mathrm{C}$, which was immunized with $33 \mathrm{kDa}$ OMP for 4 weeks. Thus, this group's serum was used for another Dot Blot test, to prove that the anti-33 kDa OMP IgG

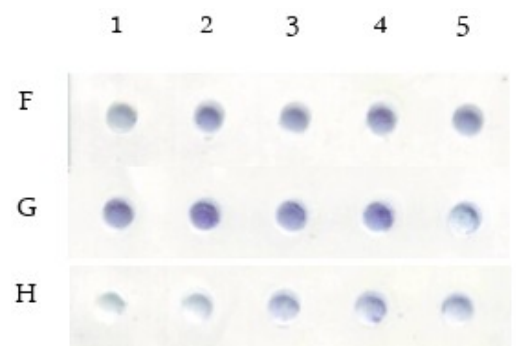

Figure 5. Dot blot assay of immune complex density on group $33 \mathrm{kDa}$ OMP immunization for 4 weeks (group C) using various antigens. There are five rat serums: (1) IgG n1, (2) IgG n2, (3) IgG n3, (4) IgG n4, and (5) IgG n5. There are also three antigens (F) OMP 33 $\mathrm{kDa},(\mathrm{G})$ crude OMP, and $(\mathrm{H})$ whole cell bacteria Streptococcus group A $\beta$-hemolytic

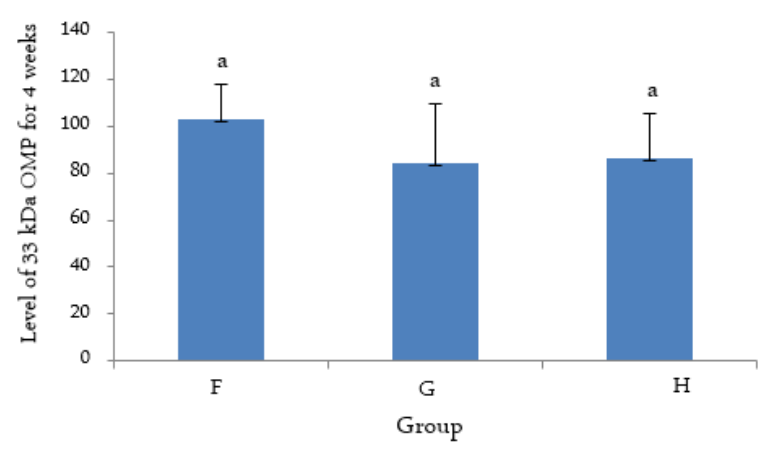

Figure 6. Level of Dot Blot on group 33kDa OMP immunization for 4 weeks (group C) using various antigens. There are five rat serums: (1) $\operatorname{IgG} \mathrm{n} 1,(2) \operatorname{IgG} \mathrm{n} 2$, (3) $\operatorname{IgG} \mathrm{n} 3$, (4) IgG n4, and (5) IgG n5. There are also three antigens (F) OMP $33 \mathrm{kDa},(\mathrm{G})$ crude OMP, and $(\mathrm{H})$ whole cell bacteria Streptococcus group A $\beta$ hemolytic 

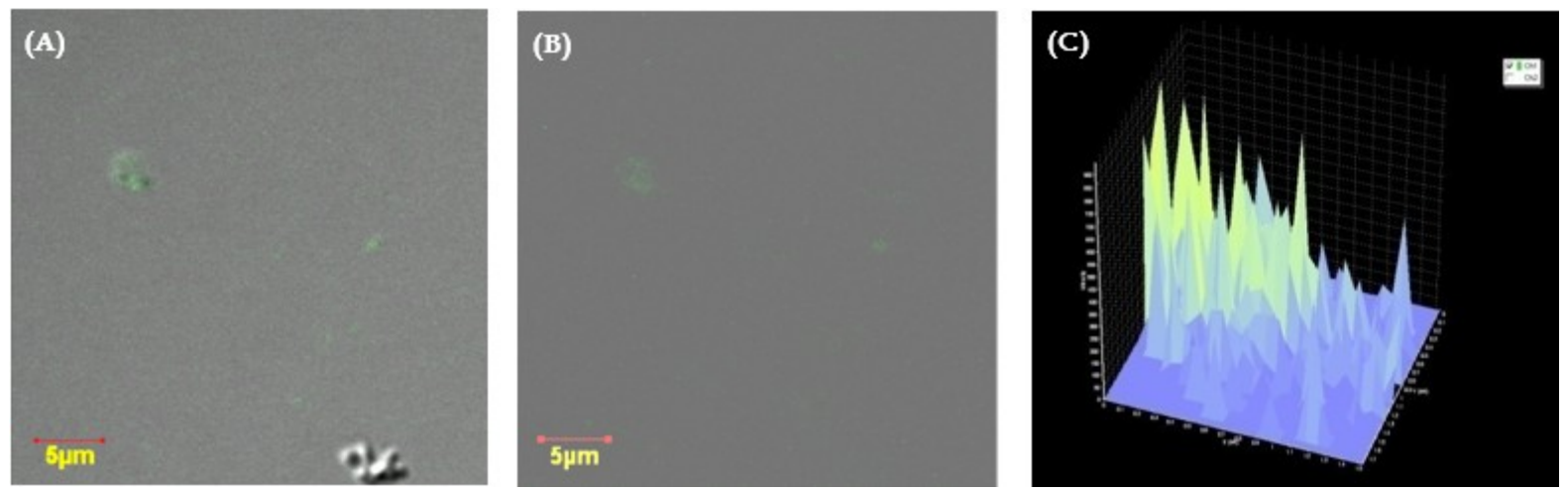

Figure 7. Immunocytochemistry results with antigen in form of whole cell Streptococcus group A $\beta$-hemolytic . FITC fluorescence labeling was done with secondary anti-rat IgG. (A) and (B) are images of confocal microscope observation with $400 \times$ magnification and zoom $9 \times$, which display there was a green color on the surface of bacterial cells. (C) Is a diagram image analysis of color intensity that appears in the image (A) and (B). This diagram shows the average value of the intensity of the color was 115.946
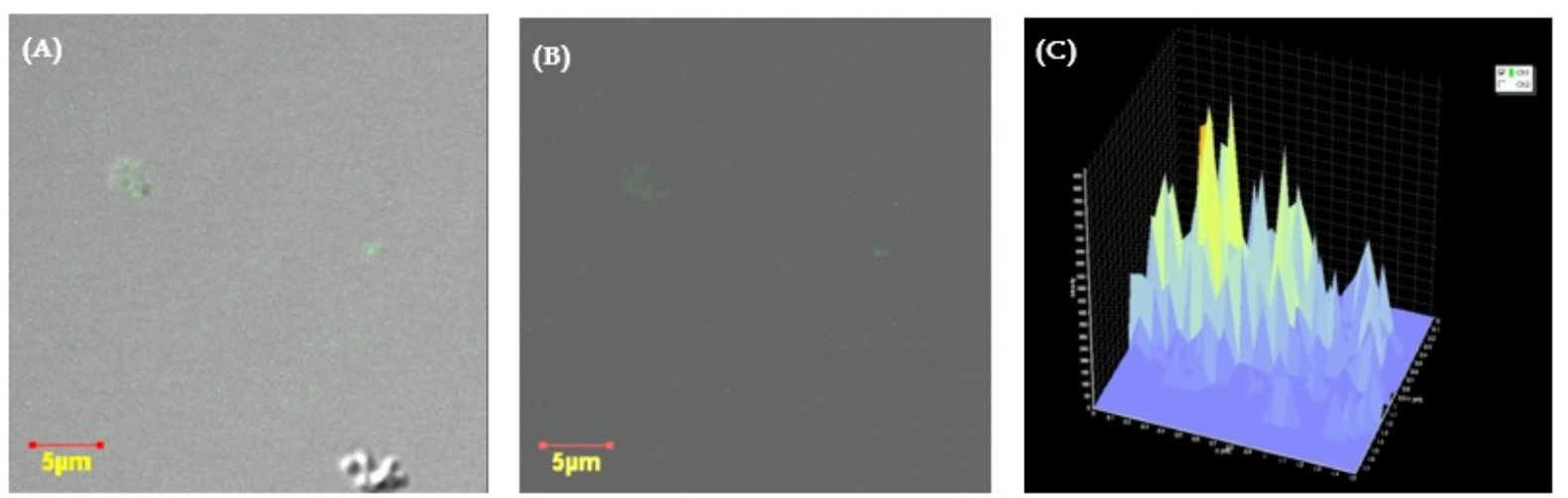

Figure 6. Immunocytochemistry results with antigen in the form of the whole cell Streptococcus group A $\beta$-hemolytic . Labelling was done with fluorescence FITC secondary anti-rat IgG. (A) and (B) are images of confocal microscope observation with $400 \times$ magnification and zoom $9 \times$ slice no-13, which display there was a green color in the middle or the cytosol of the cells. (C) Is a diagram image analysis of color intensity that appears in the image (A) and (B). This diagram shows the average value of the intensity of the color was 33.322 .

could recognize and respond the whole cell of Streptococcus group A $\beta$-hemolytic. From Figure 5, it was observed that there was a difference between these groups, albeit statistically insignificant ( $\mathrm{p}$ value $>0.05$ ).

Figure 2 showed that there were differences in the dot blot results in each group, but the differences were not statistically significant. These results were confirmed by repeated ANOVA test reporting p value > 0.05 . Mean value differences of group F (33 kDa OMP antigen) with group $\mathrm{G}$ (whole cell bacteria antigen) were not significant. This could be due to the possibility that $33 \mathrm{kDa}$ OMP was the dominant protein in Streptococcus group A $\beta$-hemolytic. However, these findings are still insufficient to conclude that the 33 $\mathrm{kDa}$ OMP may reflect or represent Streptococcus group A $\beta$-hemoliticus in general.

\section{Analysis of binding location of anti-33 $\mathrm{kDa}$ OMP IgG- with Streptococcus group $A \boldsymbol{\beta}$-hemolytic's antigen}

To find the location of antigen responded by host's $\mathrm{IgG}$, immunocytochemical examination with fluorescence labeling was done (Figure 7). Further observation was done using confocal microscope to strengthen the notion that the locations of the antigens bound by host's IgG were on the cell surface. The observation was done by slicing the bacterial cells inward (Figure 8 and 9).

There were green fluorescence color observed on the cell surface in slice no- 8 and slice no-13 as in Figure $8 \mathrm{~A}$ and $8 \mathrm{~B}$; Figure $9 \mathrm{~A}$ and $9 \mathrm{~B}$, although the color intensity values tend to decrease the deeper the slice gone inside the bacterial cells as observed in Figure 8C and $9 \mathrm{C}$. The green color or fluorescent suggested that 

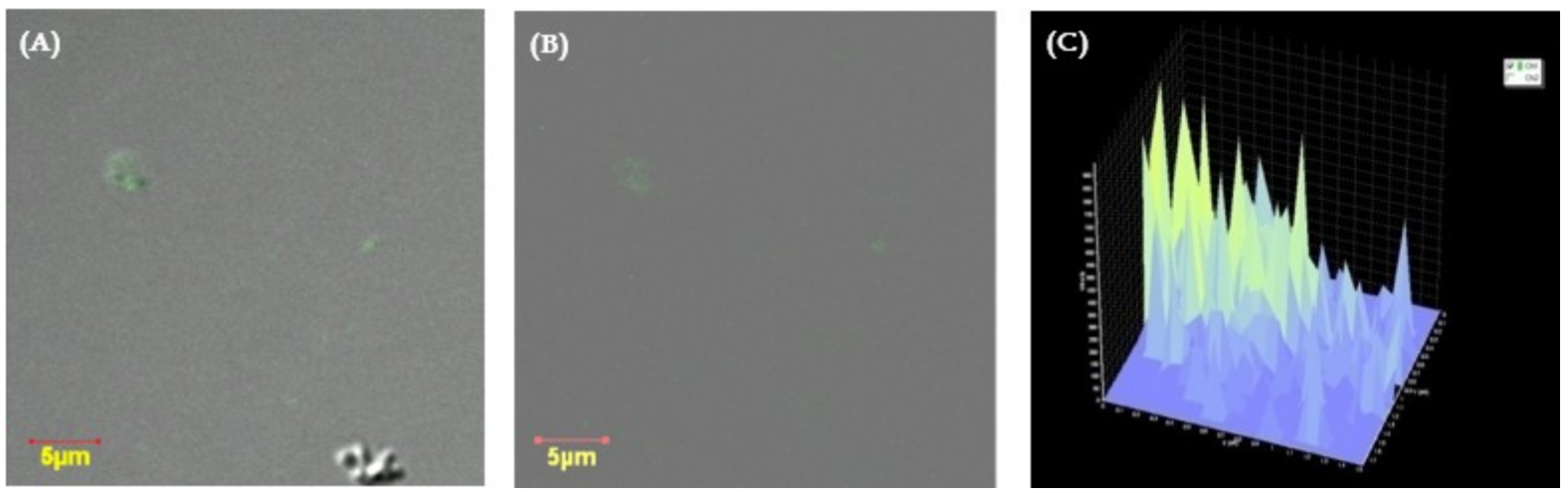

Figure 7. Immunocytochemistry results with antigen in form of whole cell Streptococcus group A $\beta$-hemolytic . FITC fluorescence labeling was done with secondary anti-rat IgG. (A) and (B) are images of confocal microscope observation with $400 \times$ magnification and zoom $9 \times$, which display there was a green color on the surface of bacterial cells. (C) Is a diagram image analysis of color intensity that appears in the image (A) and (B). This diagram shows the average value of the intensity of the color was 115.946

there were ligations between $\operatorname{IgG}$ and antigens of the cells. The brighter the color, as shown by the increasing average value of the intensity, the higher the immune complexes formed. It means that there were more immune complexes formed in the surface compared to the inside of the bacterial cell.

Immunocytochemistry results depicted in Figure 4 showed that the host's serum IgG bound to the bacterial antigen located at the outer membrane. However, this IgG was not only bind to the outer membrane, but also bind to the middle or cell cytosol (Figure 7 and 8). It can possibly happen because the IgG binds the mRNA or $33 \mathrm{kDa}$ protein which is still in the cytosol and not yet released to the cell surface. However, the mechanism of how this IgG can enter the cell and bind the m-RNA or pre-OMP-protein is not clearly understood and there is no study showing the same result yet. This is suspected due to the loss of rigidity of the bacteria cell membrane caused by immunocytochemistry procedure or by serum complement-mediated cell lysis, so the already-FITC-labeled IgG may diffuse into the bacterial cell cytosol. To prove this hypothesis, further research is needed.

\section{CONCLUSION}

The conclusions from this study are explained below:

1. The immune complex formed in the immunologic test indicate that $33 \mathrm{kDa}$ OMP was an immunogenic antigen of bacteria

2. Immunoglobulin $\mathrm{G}(\operatorname{IgG})$ in the serum of the hosts immunized with $33 \mathrm{kDa}$ OMP could recognize and respond to the whole cell of Streptococcus group A $\beta$-hemolytic. It also indicated that $33 \mathrm{kDa}$ OMP had an important role in promoting the immune response to this bacteria.

3. The immune complex density was higher in group immunized with $33 \mathrm{kDa}$ OMP than group immunized with whole cell bacteria of Streptococcus group A $\beta$-hemolytic. It is probably due to the natural history of immune response, which leads to Th2 and promotes Ig production if the stimulus given was a peptide-specific antigen. Whereas bacterial peptide antigen leads to Th1 and stimulates a cellular immune response.

4. Group immunized within 4 weeks showed higher immune complex density than group immunized within 8 weeks. It is due to host's natural downregulation of immune system

5. The binding location of IgG and the bacterial antigen was not only observed at the cell's outer membrane but also in its cytosol. It is suspected due to lysis of cell membrane caused by immunocytochemistry procedure or by complement-mediated cell lysis. Further research is needed to prove this hypothesis.

\section{ACKNOWLEDGMENT}

\section{REFERENCES}

1. WHO (2004) Rheumatic fever and rheumatic heart disease. Geneva, WHO.

2. Mayosi B, Gaasch WH, Yeon SB (2015) Natural history, screening, and management of rheumatic heart disease. http://www.uptodate.com/. Accessed: February 2017.

3. Cunningham MW (2000) Pathogenesis of group A streptococcal infections. Clinical Microbiology Reviews 13 (3): 
470-511.

4. Galvin JE, Hemric ME, Ward K, Cunningham MW (2000) Cytotoxic mAb from rheumatic carditis recognizes heart valves and laminin. Journal of Clinical Investigation 106 (2): 217-224. doi: 10.1172/JCI7132.

5. Phillips GN, Flicker PF, Cohen C et al. (1981) Streptococcal M protein: a-Helical coiled-coil structure and arrangement on the cell surface. Biochemistry 78 (8): 4689-4693.

6. Fischetti VA, Gotschlich EC, Siviglia G, Zabriskie JB (1976) Streptococcal M protein extracted by nonionic detergent. I. Properties of the antiphagocytic and type-specific molecules. The Journal of Experimental Medicine 144 (1): $32-53$.

7. Susilo J, Sartono TR, Sumarno (2004) Deteksi bakteri Klebsiella pneumonia pada sputum dengan metode imunohistokimia menggunakan anti outer membrane protein berat molekul $40 \mathrm{kDa}$ Klebsiella pneumonia sebagai antibodi. Jurnal Kedokteran Brawijaya 10 (1): 12-18.

8. Laemmli UK (1970) Cleavage of Structural Proteins during the Assembly of the Head of Bacteriophage T4. Nature 227 (5259): 680-685. doi: 10.1038/227680a0.

9. Sumarno, Susanto A, Ismanoe G (2011) Combinations of protein sub-unit PILI 37.8 KDA V. Cholerae with Cholera toxin sub-unit B V. Cholerae can protect come out of the solution in the intestinal mice. Journal of Pharmaceutical and Biomedical Sciences 1 (8): 154-160.

10. Beachey EH, Stollerman GH, Chiang EY et al. (1977) Purification and properties of $\mathrm{M}$ protein extracted from group A streptococci with pepsin: Covalent structure of the amino terminal region of type $24 \mathrm{M}$ antigen. The Journal of Experimental Medicine 145 (6): 1469-1483.

11. Dale JB, Beachey EH (1986) Localization of protective epitopes of the amino terminus of type 5 streptococcal $M$ protein. Journal of Experimental Medicine 163 (5): 11911202.

12. Harlow E, Lane D (1988) Antibodies: A laboratory manual. New York, Cold Spring Harbor Laboratory.

13. IHC World (2011) Immunocytochemistry Methods, Techniques, Protocols. http://www.ihcworld.com/. Accessed: August 2015.

14. Ghozali I (2006) Aplikasi analisis multivariate dengan program IBM SPSS 19. Semarang, Badan Penerbit Universitas Diponegoro.

15. Janeway CA, Travers P, Walport M, Shlomchik MJ (2001) Immunobiology in health and disease 5th edition. New York, Garland Publishing

16. Abbas AK, Lichtman AH (2010) Basic immunology, function and disorder of the immune system 3rd edition. China, Saunders, Elsevier Inc. 